Article

\title{
Disability, Procreation, and Justice in the United States
}

\author{
Kimberly Mutcherson \\ Rutgers Law School, 217 N. 5th Street, Camden, NJ 08102, USA; kim.mutcherson@rutgers.edu; \\ Tel.: +1-856-225-6549
}

Received: 6 September 2017; Accepted: 11 November 2017; Published: 22 November 2017

\begin{abstract}
Parenting and procreation have long been contested legal terrain in the United States as exemplified by a history of abuses against marginalized populations including people with disabilities. While some of the most egregious abuses, such as state sponsored sterilization programs, are relics of the past, it remains true that people with disabilities face distinct and at times insurmountable roadblocks to procreation and parenting. This article details ongoing forms of procreative discrimination against people with disabilities, rejects common justifications for that discrimination, and offers proposals for better protecting the rights to procreate and parent for disabled people.
\end{abstract}

Keywords: disability; procreation; parenting; discrimination

\section{Introduction}

In its history, the U.S. Supreme Court has issued decisions sanctioning bigotry, discrimination, and dehumanization in a number of forms, including based on race, gender, and national origin. It is no surprise, then, that the Court has failed in key moments to protect people living with disabilities from ill treatment at the hands of law and policymakers. Such was the case in 1927 when the Court decided the fate of a young woman named Carrie Buck in the landmark case of Buck v. Bell. Ms. Buck's legal caretakers failed to protect her from a sexual assault at the hands of one of their relatives that left her pregnant and unmarried at the age of 17. Compounding their failure, Carrie's caretakers responded to the assault and pregnancy by having Carrie committed to the Virginia State Colony for Epileptics and the Feebleminded. ${ }^{1}$ After her commitment and the birth of her daughter, Ms. Buck was targeted for sterilization as authorized by a Virginia law that permitted permanent sterilization for any person who was a "mental defective" and for whom the "the health of the patient and the welfare of society may be promoted by [ ] sterilization ... under careful safeguard ... [and] without serious pain or substantial danger to life." ${ }^{2}$

Testimony at Ms. Buck's trial sought to establish that Carrie Buck came from a family in which the affliction of mental infirmity was widespread. An expert in eugenics ${ }^{3}$ testified that Carrie's mother, Emma Buck, was also a resident at the Virginia Colony, where she had been committed because she was mentally deficient and morally degenerate, as evidenced by her purported promiscuity and the fact that she had given birth to several children outside of marriage. ${ }^{4}$ Other witnesses testified that multiple members of Carrie's family were odd and a nurse claimed that she had compared Carrie's

Buck v. Bell, 274 U.S. 200 (1927).

Id. at 205.

I use the term "expert" here loosely as these were people who lacked connection to any scientifically sound methods of evaluating the quality of an individual's genes and determining the risk that any so-called faulty genes would be passed from parent to child.

4 See (Lombardo 2001). 
infant daughter, Vivian, to another infant of the same age and that Vivian did not look "normal" though the nurse was unable to offer any specifics of what was abnormal about the child. ${ }^{5}$ The historical record would later reveal that Carrie Buck did not have an intellectual or developmental disability (IDD), nor did her daughter. Nevertheless, Justice Oliver Wendell Holmes wrote an opinion for the Court that upheld the statute and the order that Ms. Buck be sterilized. Reflecting on the specious evidence that Ms. Buck was the daughter of a developmentally disabled woman and the mother of a developmentally disabled child, Justice Holmes wrote, "Three generations of imbeciles are enough." The Court's decision in the Buck case has never been overruled.

Carrie Buck's experience, and that of the hundreds of people also forcibly sterilized during this particular period of eugenic popularity in the United States, ${ }^{7}$ are stark reminders that access to parenting and procreation has long been an area of contestation in the law. The United States has a history of sterilization abuse against poor women, women of color, and, as is clear from Buck v. Bell, people living with disabilities of various sorts. Overt forced sterilization laws are a relic of the past in the U.S., but people with disabilities face distinct and at times insurmountable roadblocks to procreation and parenting. These roadblocks include discrimination by the healthcare providers and fertility experts who could facilitate efforts to become pregnant; caretakers who reject the idea of sexual agency for people living with physical, intellectual, or developmental disabilities; inadequate social supports to facilitate parenting by people living with disabilities; and widespread cultural assumptions that those living with disabilities do not deserve or desire foundational life experiences that many people without disabilities take for granted, including the experience of reproduction and parenting.

This article details ways in which disability continues to act as a barrier to procreation and parenting, argues for the importance of recognizing and protecting the constitutional and human right to procreate for people living with disabilities, and offers practical ways that law and policy could be utilized to further the procreative desires of people living with disabilities.

\section{The Nature of Disability}

The umbrella term disability is inadequate to cover the range of life experiences that can all be said to be disabling. ${ }^{8}$ A person with a profound developmental disability experiences life differently than a person who is blind and the person who is blind experiences life differently than a person living with bipolar disorder, who, in turn, experiences life differently than a person who uses a wheelchair because she has lost use of her legs. All of these people fall under the label of being disabled according to the law, but the ways in which their disabilities impact their lived experiences, including how they are perceived by the world around them can be strikingly different. The heterogeneity of the community of people living with disabilities makes it difficult to write about disability as an all-encompassing category. However, it is fair and largely accurate to say that disability as a category, across a range of presentations, has been a space in which state sponsored or at least state approved efforts to control procreative and parental decision-making has been longstanding. Beyond the forced sterilization laws described above, private parties have used the courts to seek permission to sterilize adults living with

\footnotetext{
Id.

Id.

For a detailed account of the broad impact of eugenic thought in America, see (Lombardo 2016).

I use the term disabling here in a way that I hope indicates the complex scholarly discussion about the nature of disability that has spawned rich and persuasive literature about disability as a social construct that rejects or a least substantially complicates the medical model of disability. See, e.g., (Liachowitz 1988). I absolutely acknowledge that what makes something a disability can be the way that societies fail to accommodate the needs of bodies and minds that come in a variety of packages. That being said, it is true that a person who cannot hear or see or who is paralyzed has a condition that impacts that individual's ability to engage in certain basic life functions such that accommodation of some sort becomes necessary. This premise is what underlies the legal definition of a disability as found in the laws like the Americans with Disabilities Act, which protects those who have a "physical or mental impairment that substantially limits one or more major life activities of such individual." 42 U.S.C. §12102.
} 
disabilities, ${ }^{9}$ reinvigorating debates about the circumstances, if any, in which one person should be able to consent to sterilization on behalf of another. People with disabilities too frequently have to defend their right to parent, sometimes even in court, because of assumptions about their abilities or lack thereof as caretakers. ${ }^{10}$ People with disabilities who seek infertility treatment may find themselves shunned by physicians who make presumptions of parenting ability even when they have no expertise in making such judgments ${ }^{11}$ or because they fear the impact of a pregnancy on a particular patient's health. ${ }^{12}$ Finally, people with disabilities may find themselves defending their right to have children who share their disability by taking deliberate steps to increase the chance of having a child with a disability ${ }^{13}$ or by declining to use technology that could virtually guarantee the birth of a child who would not have a disability. Obviously, not all people living with disabilities have the same life experiences, just as not all people of color and not all women share the same experiences though they sit in a similar identity category. Nevertheless, there is a subset of shared discrimination worthy of attention.

The lives of countless people living with a range of disabilities have improved in the decades since Buck v. Bell. Key federal statutes such as the Rehabilitation Act, ${ }^{14}$ the Americans with Disabilities Act ("ADA"), ${ }^{15}$ and the Individuals with Disabilities Education Act (IDEA) ${ }^{16}$ create obligations for various actors, including public accommodations such as schools, stores, and physician offices to make themselves accessible to people with disabilities. The idea that people with disabilities should be shunned or dismissed from the goods offered to others in society no longer holds sway in the context of lawmaking. Nevertheless, procreation and parenting remain areas in which there is a righteousness about the belief that some choices should be limited or forbidden altogether generally to benefit children or the larger society.

\section{The Right to Procreate}

Issues of procreative discrimination based on disability span the globe. However, this article focuses on the United States as a specific site of such discrimination. In the United States, procreation is ostensibly a fundamental right for all under the U.S. Constitution. In 1942, the U.S. Supreme Court again faced a case that involved a challenge to a non-consensual sterilization law different in scope from the law at issue in Buck $v$. Bell, but with similar intent-prevent procreation by those deemed to possess unworthy genes. Unlike Carrie Buck, the mark against Jack Skinner was his status as a recidivist felon

9 See, e.g., (Supreme Court of California 1985) (parents sought a court order allowing them to consent to a sterilization procedure for their adult developmentally disabled daughter); In re Moe, 432 N.E.2d 712 (mother of developmentally disabled adult daughter sought court permission to consent to a tubal ligation for her daughter); In re Guardianship of Hayes, 608 P.2d 635 (1980) (mother sought permission to consent to sterilization for her adult developmentally disabled daughter); In the Matter of C.D.M., K.C.M. E B.L.M., 627 P.2d 607 (1981) (parents sought permission to consent to tubal ligation on behalf of their developmentally disabled daughter); In re Grady, 426 A.2d 467(1981) (parents sought permission to consent to sterilization on behalf of their daughter who was living with Down Syndrome.); In re Johnson, 263 S.E.2d 805 (1980) (court allowed unconsented sterilization of developmentally disabled woman under N.C. statues over the woman's objections).

10 See (National Council on Disabilities 2012), ("Removal rates where parents have a psychiatric disability have been found to be as high as 70 percent to 80 percent; where the parent has an intellectual disability, 40 percent to 80 percent. In families where the parental disability is physical, 13 percent have reported discriminatory treatment in custody cases. Parents who are deaf or blind report extremely high rates of child removal and loss of parental rights.").

11 Id. at 23-24.

12 Some health conditions that increase pregnancy risks for women include Turner syndrome, a genetic disorder experienced only by women, or women with significant cardiac conditions such as peripartum cardiomyopathy (weakening of the heart muscle), and persistent left ventricular dysfunction. See (Ethics Committee of the American Society for Reproductive Medicine 2016).

13 See (Spriggs 2002); see (Sanghavi 2006).

14 The Rehab Act was an early piece of legislation that prohibits discrimination against people with disabilities in Federal programs, including programs that receive federal funding, and federal employment, including companies that receive contracts from the federal government.

15 The ADA extends the protections of the Rehab Act to state and local governments, public accommodations, commercial facilities, transportation and telecommunications.

16 The IDEA creates affirmative obligations for public schools to make education available to children with living disabilities in the least restrictive environment. 
and he was slated to be sterilized without his consent in keeping with Oklahoma's Habitual Criminal Sterilization Act. ${ }^{17}$ The law targeted individuals who had been convicted of at least three "felonies involving moral turpitude", though some felonies, mostly white-collar crimes, were excluded from the statute. ${ }^{18}$ For those whose crimes were included in the statute's purview, the state could require vasectomy for men or tubal ligation for women to render them surgically sterile, which would avoid the risk that they would pass on their criminal tendencies to their children through their genes or simply parent their children into a life of crime. In Skinner, without overruling Buck, the Supreme Court took the position that this forced sterilization statute offended the Constitution's guarantee of equal protection by allowing sterilization for some felons and not others. ${ }^{19}$ Though the Court spent little time considering the value of procreation in its Buck opinion, in Skinner, the justices wrote:

$[\mathrm{M}]$ arriage and procreation are fundamental to the very existence and survival of the race. The power to sterilize, if exercised, may have subtle, far-reaching and devastating effects. In evil or reckless hands[,] it can cause races or types which are inimical to the dominant group to wither and disappear. There is no redemption for the individual whom the law touches. Any experiment which the State conducts is to his irreparable injury. He is forever deprived of a basic liberty. ${ }^{20}$

Many scholars and subsequent courts have construed this language as standing for the proposition that procreation is a fundamental right. ${ }^{21}$ Like all fundamental rights, the right to procreate is not boundless, and the Court stopped short of making a claim that the state could never force sterilization. The Justices did, however, make clear that when statutes touched on this "basic liberty", the right to procreate, courts would subject those statutes to an exacting level of judicial scrutiny.

The U.S. Constitutional scheme is but one source of a broadly protected right to procreate. Such a right also exists in foundational human rights documents. As recognized by the United Nations:

[R]eproductive rights embrace certain human rights that are already recognized in national laws, international laws and international human rights documents and other consensus documents. These rights rest on the recognition of the basic rights of all couples and individuals to decide freely and responsibly the number, spacing and timing of their children and to have the information and means to do so, and the right to attain the highest standard of sexual and reproductive health. It also includes the right to make decisions concerning reproduction free of discrimination, coercion and violence, as expressed in human rights documents. ${ }^{22}$

Specifically, in the context of people living with disabilities, the Convention on the Rights of Persons with Disabilities (CRPD), to which the United States is a signatory, makes clear that the general rights to found a family and raise one's children extend equally to people living with disabilities. ${ }^{23}$ The Convention holds that States Parties "shall take effective and appropriate measures to eliminate discrimination against persons with disabilities in all matters relating to marriage, family, parenthood and relationships on an equal basis with others ..." 24 The Convention requires States to recognize the right of people living with disabilities to make procreative decisions, such as the number of children to have, if any, the spacing of those children, and access to appropriate education about family planning and the means to plan their families as they choose. ${ }^{25}$ Critically, the Convention

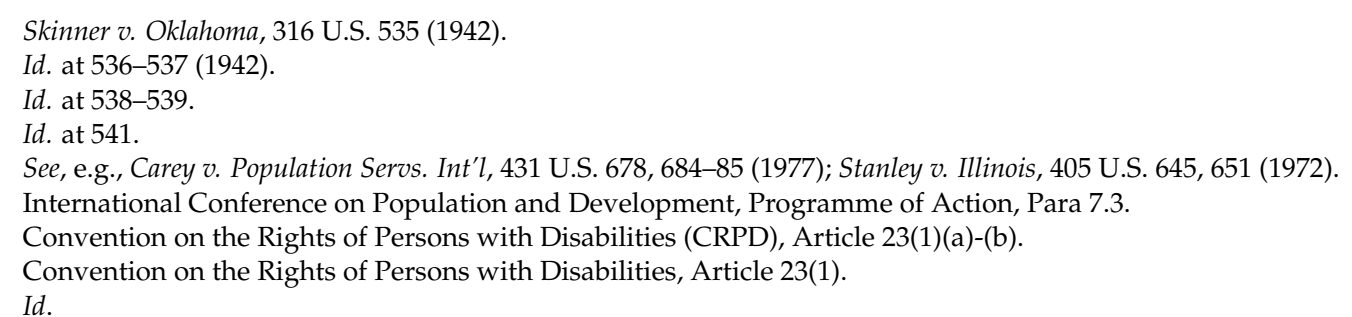


makes clear that "Persons with disabilities, including children, retain their fertility on an equal basis with others" 26 thus, responding to and rejecting the acceptability of forced sterilization for people living with disabilities, including children. ${ }^{27}$ Finally, in the realm of parenting, in addition to requiring that states protect the rights of parentage and caretaking for people with disabilities, States are also exhorted to "render appropriate assistance to persons with disabilities in the performance of their child-rearing responsibilities." ${ }^{28}$ Assistance of this type is critical where a parent with a disability needs social support, financial or otherwise, in order to parent adequately her children.

As a matter of U.S. Constitutional law and human rights principles, people with disabilities have the same rights of procreation and parenting afforded to all people. The constitutional rights to procreate and parent are largely negative rather than positive, meaning that the government is limited in its ability to interfere with a disabled individual's right to parent or to have children, but typically has no affirmative obligation to assist a disabled person who is seeking pregnancy or who has needs that must be met in order to facilitate her ability to parent. ${ }^{29}$ Where there are surmountable barriers to parenting, however, human rights principles require a more robust response from the State and affirmative efforts to aid those who procreate or parent while living with a disability. Taken together, the law and human rights principles make a strong case for increased focus on making the law more friendly to and cognizant of the needs of parents or would-be parents who are disabled. Despite this, barriers to parenting and procreation persist largely due to myths and misconceptions about the lives of people with disabilities.

\section{Justifications for Limiting Access to Procreation for People with Disabilities}

The treatment of disability in law and policy related to procreation must be understood within the broader context of what Ricki Solinger has called reproductive politics. According to Solinger, reproductive politics refers "most basically to the question, Who has power over matters of pregnancy and its consequences?" 30 While the U.S. constitutional order often locates rights related to procreation and parenting in the sphere of privacy, the existence of reproductive politics makes clear that what is private for some is a matter of public concern and state control for others. And when the state exercises control over matters of procreation involving people with disabilities, it frequently relies on justifications that cannot legitimately support burdening a fundamental right.

Limitations on access to parenting for the disabled can be structural and systemic as well as personal and localized. State sponsored sterilization programs were a systemic way to prevent certain people from ever having children when possible including people with disabilities, but those programs were also racist and classist. This truth is exemplified by the experience of the Relf sisters, two developmentally disabled Black girls, sterilized in 1973 at the ages of 14 and 12 at a federally funded healthcare facility after their mother signed a consent form with an " $X$ " because she was illiterate. ${ }^{31}$ The Relf sisters were part of a long line of women (poor, disabled, Black or Brown) for whom people with power decided procreation was a luxury best denied largely because of myths about so-called irresponsible procreation, inadequate parenting, and hyper sexuality. Thus, intersectional identities, including the intertwining of disability with other indicia of marginalization, impact the power dynamics of reproductive oppression, such that being young, poor, Black, and disabled all played a role in the sterilization experience of the Relf sisters. I make this point to make clear that I do

\footnotetext{
CRPD, Article 23(1)(c).

CRPD, Article 23(2).

Id.

There are statutory exceptions to the general rule that these rights are negative such as when the state child welfare system becomes involved with a family due to accusations of abuse or neglect and the state assumes an obligation to assist the parent in correcting the conditions that led to state supervision.

30 See (Solinger 2005).

31 This particular act of state sponsored abuse eventually led to change in consent procedures under guidelines to that public hospital and other facilities receiving public funds are bound to follow. See (Southern Poverty Law Center n.d.).
} 
not seek to essentialize the experiences of all disabled women, but to make clear that there are women within the disabled community whose rights are at greater risk than is true for others.

More personalized discrimination comes in the form of individual healthcare providers who are unwilling or unable to provide a level of care necessary to help a woman with a disability become pregnant or carry a pregnancy to term. Some healthcare professionals have been candid about the medical field's failure to provide sufficient healthcare resources to women with disabilities who are pregnant and seeking care noting that "[m]any women with disabilities report difficulty finding a health care provider with experience in providing obstetrical care to women with disabilities or who is willing to assume care for them during pregnancy". ${ }^{32}$ Furthermore, "women with disabilities that limit their mobility have reported inaccessible physician offices and clinics, not being weighed even once during their pregnancy, and receiving no help in transferring to a high, non-adjustable exam table in the absence of an adjustable table". ${ }^{33}$ Unsurprisingly, when women cannot find adequate obstetrical care, it can discourage them from seeking pregnancy at all or can make their pregnancies less safe for them and the babies they seek to carry to term.

Two primary lines of thought used to justify procreative and parenting restrictions for women with disabilities have deep historical roots. The first is the idea that people living with disabilities risk passing those disabilities to their children thereby keeping supposedly flawed genes in the gene pool. The second is that people with disabilities will be inadequate parents and therefore should not have children who will suffer from their abuse or neglect. To this, I add a third claim which is that people with disabilities, or at least some people with IDDs, are presumed incapable of consenting to sex and therefore should not be able to have the kind of intimate relationships that could lead to a child being born. I will respond to each of these claims in turn.

\subsection{Sex and Disability}

Starting with the third claim, a significant source of difficulty for people living with disabilities is that the wider world does not always view them as having sexual desires and sexual agency, which precludes them from having the ability to be sexually active on their own terms, especially when doing so requires assistance from others. As one author explained, for decades "[t]he public discourse surrounding sex and severe disability ... largely focused on protecting vulnerable populations from abuse". ${ }^{34}$ Studies have revealed that sex and access to sex are fraught for many people living with significant physical or intellectual disabilities both because of concerns about abuse, which lead to laws and policies that impede access to sex, and because physical or other limitations can make it difficult to find sexual partners. ${ }^{35}$ As one author wrote, "We live in a society where many individuals seem unaware that disabled people have sex, enjoy sexuality, and are at some unique risks in terms of reproductive health". ${ }^{36}$ Unfortunately, it continues to be the case that many people infantilize and desexualize people who are living with disabilities, especially IDDs. ${ }^{37}$ The presumption that people are childlike simply because their bodies are small or that they lack sexual desire because they cannot walk or that they are incapable of understanding or consenting to sex because they have a mental illness are all reasons that the sexual dynamics of procreation are too often seen as outside of the capabilities or interests of people with disabilities. This failure to treat people with disabilities as individuals with sexual desires and sexual agency can lead to unintended consequences. As one author explains,

\footnotetext{
See (National League for Nursing 2017).

Id.

See (Appel 2010), (arguing for a positive right to sex for people living with disabilities, including altering rules forbidding sexual relationships in institutional settings and creating carve out in prostitution prohibitions on behalf of people with disabilities). But see (Di Nucci 2011), (arguing against the existence of a positive right to sexual pleasure that could require financing by the state).

35 See (Kulick and Rydström 2015).

36 See (Smith 2014a).

37 See (Friedman and Owen 2017).
} 
"because society as a whole thinks that disabled people do not and cannot have sex, members of the public, law enforcement, policymakers, and even medical professionals have difficulty conceiving of the idea that they might be targets for rape and assault. This leaves disabled people, particularly those in institutional care or under the 'care' of abusive individuals, vulnerable to danger". ${ }^{38}$

It is well documented that some individuals take advantage of vulnerabilities possessed by some people with disabilities. Abuse takes place in private homes, in public facilities, and in other settings. ${ }^{39}$ Among developmentally disabled adults, one study found that $85 \%$ of females and $32 \%$ of males are sexual assault survivors. ${ }^{40}$ In another study, forty percent of women with physical disabilities reported being sexually assaulted. ${ }^{41}$ These numbers are unconscionable and speak to a deep need to find more and better ways to eliminate sexual assault across the board and especially in communities whose members are victimized at such high rates. That being said, for individuals who are capable of consenting to sexual activity, the stereotypes of sexless people with disabilities are unsupportable. For others, though, who are truly incapable of understanding or consenting to a sexual relationship, the concern that they should be protected from those who would hurt them and from the potential consequences of sexual exploitation is valid.

Protecting those who need it from sexual assault involves a number of potential policy shifts, including providing better sexual health education to people living with disabilities, including adolescents, to ensure that they have the tools to recognize and report sexual exploitation, ${ }^{42}$ ensuring that healthcare providers and caretakers respect the capacity for consent that people with disabilities possess; and, of course, enforcement of laws and policies that punish perpetrators and remove them from roles that allow them to do harm. Equally as important, attempts to protect the vulnerable should not bar the hopefully rich and fulfilling life experiences of procreation and parenting, or just sexual pleasure, for those people living with disabilities who desire it. Walking this line is difficult, but it is a critical distinction to make so that people are not unfairly deprived of rights. ${ }^{43}$ Part of the necessary work here is making sure that courts and decision makers do not paint all people with disabilities with a single brush, but take the time to ascertain both the capacity to consent and the presence of actual consent when faced with a question of sexual contact involving a person with disabilities. These evaluations will not always be easy, but they are required to protect the decisional autonomy of disabled people with the capacity to make their own decisions about sexual experiences, even if those decisions are not always well-considered or in their best interest, just as is true for any person with the capacity to consent to sexual activity.

\subsection{Disability and Parenting}

The second issue is the concern that people who are living with disabilities will be neglectful or abusive parents. This concern partially explains why parents with disabilities, especially those with mental health disorders, are overrepresented in the ranks of parents forced to interact with state child welfare systems. ${ }^{44}$ Further, disability is an acceptable status for rejecting would-be parents who wish to adopt children ${ }^{45}$ or for selecting one parent over another in a child custody proceeding. ${ }^{46}$

38 s.e. Smith, supra note 36.

39 See, e.g., (Euser 2016) (citing research concluding that children with disabilities have an increased prevalence of all kinds of abuse, include sexual abuse).

40 See (Johnson and Sigler 2000).

41 See (Young et al. 1997).

42 s.e. smith, supra note 36.

43 For a devastating case of how difficult questions of consent and agency can become when people with significant disabling conditions are involved, see the case of Anna Stubblefield, a tenured university professor convicted of sexually assaulting a profoundly disabled man with whom she claimed to be able to communicate using controversial facilitated communication techniques. See (Engber 2015).

44 National Council on Disability, ROCKING THE CRADLE, supra note 10, at 17-21.

45 Ibid. at 20.

46 Ibid. at 22. 
While few people would claim that parenting ability is an irrelevant factor when it comes to the welfare of children, the question of who should be able to make assessments of such ability, the criteria for those assessments, and when assessment is warranted are the crux of this discussion.

Ascertaining what kind of parent a person will be is an imprecise process unless and until a person actually assumes a parental role. Suppositions based on stereotypes about people living with disabilities are a poor substitute for individualized assessments of capacity. Further, it is questionable whether anyone should take it upon themselves to play the role of decision-maker about someone else's parenting prowess in the absence of quality information about what that person brings to the table as a parent. Many people living with disabilities have rich support systems in place that play a critical role in how they parent, something that all parents, no doubt, could use. In keeping with the precepts of the CRPD, where such support does not exist, it is appropriate for public funding to exist to assist parents with disabilities in maintaining close ties to their children and parenting to the best of their ability. Further, having learned to live and thrive with their own disabilities, many parents, especially those living with a disability that their children share, will be able to instill a measure of resilience in their children that parents who do not have disabilities might not be able to replicate. Thus, parenting ability should not be measured in a vacuum, but must be contextualized based on individual ability and the scaffolding of support from others that can enhance that individual ability.

Though not always discussed as such, the issue of parenting by people with disabilities cannot be separated from the reality that the right to procreate in the first instance may depend on a forward-looking supposition about ability to parent. Thus, the relationship between procreation and parenting warrants further exploration in this context. Typically, in the general population, the instances in which parenting ability acts as an initial barrier to procreation are few. In other words, for most people, the point at which parenting becomes questioned by the state in a way that has consequences is if and when a parent comes into contact with the child welfare system after a child is born or when a subsequent child is born into a family that has already had dealings with child welfare. ${ }^{47}$

People living with disabilities who seek to procreate must battle overblown or unfounded fears that their parenting poses risks to children simply by dint of their existence as people with disabilities. This narrative of parental incompetence exemplifies how the social construction of disability, in this case crippling low expectations for people living with disabilities who parent, become what disables the parental aspirations of disabled people rather than the disabilities themselves. These low expectations of parental ability can mask prejudice toward people living with disabilities and give those who wield them the chance to claim that they are acting not to disadvantage parents with disabilities, but to protect future children from the harm of substandard parenting.

Using this concern for children to support discrimination in procreation and parenting for people living with disabilities illustrates how assumptions that a right to procreate depends on an interest and ability to parent works to the disadvantage of people living with disabilities. ${ }^{48}$ No doubt, many, if not most, people who procreate, do so with the intent to parent, even if reluctantly. But to the extent that a right to procreate exists, it need not be premised on either a desire to or an aptitude for parenting.

47 To be clear, I do not mean to suggest that the government is completely hands off when it comes to procreation, especially when it comes to disenfranchised populations. Welfare caps for poor women, ongoing sterilization abuse, overrepresentation of people of color in state child welfare systems, and abortion restrictions are all ways in which reproduction is tiered in the United States. But, it remains the case that our Constitution seems to disfavor pre-emptive bans on procreation.

48 For a more fleshed out analysis of the distinctions among sex, parenting, and procreation, see (Mutcherson 2015), in which the author argues that it is vital to recognize that parenting, sex, and procreation are distinct experiences all worthy of Constitutional recognition and protection and none of which should necessarily rely on the others in order to have such protection. Examples of how these three significant life experiences can exist without either of the others include women who contract to act as gestational carriers and give birth to children with whom they will have no genetic connection who they will not parent. Intended parents who commission a surrogacy may parent without procreating and without having sex. Similarly, a woman who sells her eggs to another so that the purchaser can produce a child can be said to be procreating in the sense that she is replicating her genes, but, like the gestational surrogate, she does so without an intent or interest in parenting. Thus, these separate strands of human experience can be intertwined or distinct. 
This position was articulated by a dissenting justice in Conservatorship of Valerie N.-a case decided by the California Supreme Court in 1985.

In that case, the justices were faced with making a decision about surgical sterilization for Valerie, an adult woman living with Down syndrome, whose parents and conservators sought to consent to a sterilization procedure on Valerie's behalf. ${ }^{49}$ The California statutory scheme, created in response to California's history of eugenic sterilizations of people living with disabilities, did not allow for the sterilization of a person who was incapable of consenting to the procedure. In other words, it was not possible for a guardian to consent to sterilization on behalf of a decisionally incompetent ward, which meant that a ward in that situation could never be sterilized. ${ }^{50}$

Given the larger statutory scheme that sought to maximize opportunities for personal fulfillment for people living with disabilities, the majority of the members of the California Supreme Court took the position that Valerie's right to avoid procreation was violated within a statutory scheme that did not allow someone to consent to sterilization on her behalf when she was incapable of consenting for herself. The Court's rationale hinged on the idea that for a person like Valerie, who lacked decisional capacity, being fertile meant that her parents felt obliged to restrict her activities in a way that was otherwise not beneficial to her in order to avoid the risk of sexual exploitation and potential pregnancy. ${ }^{51}$ Valerie's caregivers testified that she was sexually aggressive with men and that she had not been amenable to taking birth control pills. ${ }^{52}$

In dissent, Chief Justice Bird wrote that the right to procreate is "constitutional" not in the sense of deriving from our Constitutional order but in the sense that it is a truly natural right that precedes and supersedes the Constitution. She explained:

[T] he right to procreate is more than a byproduct of a right of choice. Its roots go deeper; they are constitutional in the physical sense, implicating the individual's rights to physical integrity and to retention of the biological capabilities with which he or she was born into this world. Hence, even in the case of a mentally competent individual, it is somewhat illogical to treat the right to procreate solely as a matter of control over basic personal decisions. ${ }^{53}$

Thus, according to Justice Bird, in keeping with this view of the roots of a right to procreate, one need not be capable of parenting, desirous of parenting, or engaging in conscious decision making about procreation in order to possess a right to procreate. This is a broad vision of the right to procreate that casts a wide net of protection.

In sharp contrast to this idea that procreation and parenting need not, indeed, should not be intertwined, others have taken the position that one who cannot parent in accordance with some minimum standard of quality parenting has no right to procreate at all. In her writing about procreation and individuals with IDDs, Professor Bonnie Steinbock has argued that the right to procreate presupposes an ability to provide a minimum standard of parenting. She explains that the right to procreate encompasses more than "mere genetic replication" which would lead to the conclusion that "anyone capable of reproducing has the right to reproduce ... " Instead, the bedrock of a right to procreate is that "it is the usual way of establishing a family, of creating children that one will rear... Genetic replication where this is not linked to rearing children may be an interest that

\footnotetext{
Conservatorship of Valerie N., 707 P.2d 760, 761-763 (1985).

Id. at 770 .

51 The Court ultimately did not allow for the sterilization to take place because of procedural failures in the lower court proceeding. Among other issues, the Court raised concern that there had been no evidence in the trial court that Valerie was fertile or that other forms of birth control, besides contraceptive pills, had been tried before resorting to a request for surgical sterilization. Id. at 777-778.

52 Id. at 763.

53 Id. at 786 (C.J. Bird dissenting).
} 
some people have, but it is not an interest that society should be concerned to protect" ${ }^{\prime \prime}$ For Steinbock, then, a person who lacks the capacity to parent has no claim to a right to procreate.

Justice Bird's conception of the right to procreate sounds in law, while Steinbock's conception sounds in philosophy and morality, but they represent distinct and conflicting visions of the relationship among disability, parenting, and procreation. Justice Bird's articulation of the right is more in line with the broader right to procreation and fertility espoused in the CRPD and the fundamental nature of the right to procreate.

A broad articulation of a right to procreate that does not hinge on parenting ability does not mean that the law should ignore the needs of children born to parents living with disabilities. As is true of any child, the state has an obligation to act in the role of parens patriae for children of parents with disabilities. Thus, where these parents are incapable of meeting a minimum standard of parenting, the state is obliged and allowed to act in the interest of those children up to and including removing the children from the care of their parents or even terminating parental rights. However, when the state acts, it must do so without prejudice about the parenting abilities of people living with disabilities.

Unfortunately, stories abound of governmental entities that acted without due regard for both the rights and abilities of parents living with disabilities. In 1988, a deaf mother of two young children, who was also a domestic violence survivor, battled the child welfare system in New York City to keep her children out of foster care. According to a lawyer for the children, city workers failed to make required efforts to help the woman find adequate housing for herself and her two children and never found a sign language interpreter to assist them in communicating with the mother. ${ }^{55}$ In 2014, a British couple, both of whom are developmentally disabled, lost custody of their child for 18 months before a court returned the child to them and awarded them damages. ${ }^{56}$ It is estimated that 40 to $80 \%$ of parents with IDDs have their children taken away from them by the state. ${ }^{57}$ Though the ADA does provide some protection for parents with disabilities who find themselves battling the child welfare system for the right to raise their own children, if parents do not have qualified legal representation to pursue their rights, they risk losing their relationships with their children.

Combatting discrimination against parents and would-be parents with disabilities requires recognizing the complexity of lived experiences of people with a variety of disabilities. First, parenting ability should not act as a blanket legal barrier to procreation. Second, existing anti-discrimination laws must be enforced both so that people with disabilities can access needed health services to assist in becoming pregnant and maintaining healthy pregnancies, and so that they are privy to the services they need and to which they are entitled in order to keep their families intact. Third, judges, child welfare workers, law and policymakers, and others who make decisions about the rights of disabled parents must be well educated about the strengths of people living with disabilities who parent. ${ }^{58}$

It is vital to explode myths about the parenting abilities of people living with disabilities because those myths hurt those who parent and are equally pernicious for children deprived of parental nurturing or care because of such myths. Additionally, de facto or de jure limitations on parenting imposed on adults living with disabilities send a message to children with disabilities about their worth and about the futures that they can and should imagine for themselves. To the extent that a person living with a disability desires procreation and parenting, she should benefit from an assumption of competence unless proven otherwise.

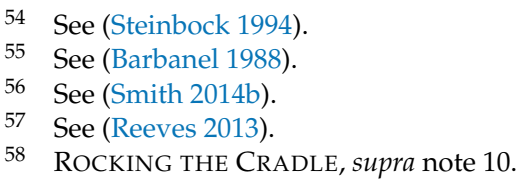




\subsection{Reproducing Disability}

The third concern used to justify limitations on parenting for people living with disabilities is that in some instances those would-be parents risk passing along their disability to their children. Of course, most people living with disabilities do not have transmissible disabilities. For others, if they so choose, there are ways to avoid passing on disabilities. For instance, a woman living with HIV who becomes pregnant can access interventions that make the risk of HIV transmission from the woman to a child to whom she gives birth less than one percent. ${ }^{59}$ But, for some number of those who live with disabilities that are genetic in origin, every pregnancy raises the possibility of giving birth to a child who shares his/her parent's condition. As described earlier, cases such as Buck v. Bell made clear that the state has an interest in preventing the legacy of disability being passed down from parent to child and the presumed cycle of dependence that would flow from that genetic legacy. Though Buck remains good law, societal understanding of and tolerance for disability has increased along with our knowledge of genetic transmission and the knee jerk belief that disability should be avoided at all costs is a more complicated conversation than it was in the early twentieth-century.

The availability of prenatal testing and pre-implantation genetic diagnosis (PGD) used in conjunction with IVF makes it possible for future parents who have a genetically based disability to opt to discover information about an embryo or fetus that will allow them to discard any embryo or abort any fetus that shares a parent's disability. For those who believe that it is always better to avoid giving birth to a child with a disability if that is possible, these technologies are a boon. For other women, however, for whom sharing a disability with a child is a preference, PGD can be used to detect the presence of disability specifically to create a child who will be disabled. In either case, selecting for or selecting against disability, the parental choices are controversial.

Debates about prenatal testing and disability are not new and they resonate just as strongly in the world of PGD. As Adrienne Asch and Erik Parens explained in their seminal article outlining the disability rights critique of prenatal testing, "using prenatal tests to prevent the birth of babies with disabilities seems to be self-evidently good to many people". ${ }^{60}$ However, for those who believe that "living with disabling traits need not be detrimental either to an individual's prospects of leading a worthwhile life, or to families in which they grow up, or to society at large", decisions to avoid the birth of a child with a disability are made based on misinformation in the context of pervasive discrimination against people with disabilities, and express disdain for the lives of people with disabilities. ${ }^{61}$ The cure for disability offered by prenatal or pre-implantation testing is to prevent a life from coming to fruition if the person living that life will be disabled. As new technologies bloom, such as gene editing with CRISPR, ${ }^{62}$ we can expect that the pressure for women to use technology to avoid disability in children will be strong.

Many in the disability community fear that actions of this sort encourage or justify negative attitudes toward disability in general by promoting the idea that it is better not to be born at all than to be alive and disabled. ${ }^{63}$ Thus, the push for prenatal and pre-implantation testing works in a circular way to reinforce the negative attitudes about disability that lead to women with disabilities being treated as "unfit' for sexual relations and for motherhood". ${ }^{64}$ While U.S. society has progressed sufficiently so that many within and outside of the disability community see great value in the

\footnotetext{
59 See (U.S. Department of Health and Human Services 2017).

See (Asch and Parens 1999).

1 Ibid at $\mathrm{S} 2$

2 CRISPR is gene editing technology that holds promise for the prevention and treatment of several genetic diseases. (U.S. National Library of Medicine 2017), What are genome editing and CRISPR-Cas9? Available at https://ghr.nlm.nih. gov/primer/genomicresearch/genomeediting.

63 See (Kaplan 1994).

64 See (Solinger 2013).
} 
"forms of variation" 65 that disability brings to the human experience, others, including too many medical professionals, still see disabled bodies as unworthy of reproduction and unworthy of life.

Given the broadly held belief that women with disabilities, and all women, should seek to avoid having children who will have disabilities when the option to do so exists, ${ }^{66}$ women who opt to create a child with a disability will find that this choice does not receive universal praise. In 2006, an article in the journal Fertility and Sterility revealed that about 3\% of clinics providing IVF in the United States had used PGD intentionally to select an embryo that would produce a child with a disability at the request of the parents. ${ }^{67}$ Many other clinics and practitioners make clear that they will not transfer genetically anomalous embryos even at the patient's request. ${ }^{68}$ Even without PGD, it is possible for people with disabilities to select for genetic anomalies. For instance, a Deaf ${ }^{69}$ lesbian couple used deaf sperm donors to increase the chances that they would bring Deaf children into their family, which they succeeded in doing. When their story received media attention, they were the subject of broad criticism for their procreative decisions. ${ }^{70}$ Choices of this type have been described as negative enhancement, ${ }^{71}$ and, unsurprisingly, have caused raucous ethical debate.

In considering the decision to seek a deaf sperm donor to increase the chances of giving birth to a deaf child, well-known bioethicist and law professor R. Alta Charo said, "I think all of us recognize that deaf children can have perfectly wonderful lives... The question is whether the parents have violated the sacred duty of parenthood, which is to maximize to some reasonable degree the advantages available to their children. I'm loath to say it, but I think it's a shame to set limits on a child's potential". ${ }^{72}$ The issues here return us to the discussion of what it means to be a person with a disability and how to value and understand the lives of those who are disabled.

It is easy to dismiss the desires of someone who explicitly wants to replicate her genes by having a child, even if those genes include genetic anomalies, but everyone who engages in coital reproduction is also replicating genes often with no knowledge or care about potential genetic anomalies lurking in their own genome. Part of what it means to have a fundamental right to procreate and to found a family is that one gets significant latitude in terms of when, with whom, and how to make babies and parent them. While it is not a perfect comparison, it is certainly the case that the state could not infringe the fundamental right of a deaf person to marry and procreate with another deaf person for fear of creating of deaf child. Similarly, the state could not prevent two people with dwarfism from using technology to avoid implanting an embryo that was destined to be a person with dwarfism. For the state to deny a person with a disability the opportunity to procreate on the same basis as someone who is not disabled is both to deny equality and the fundamental liberty of procreation to people on the basis of disability.

None of this is to say that any specific healthcare provider is bound to engage in any medical practice that she finds unethical. As the ASRM explains, "Valid and reasoned arguments exist to support provider decisions to assist in transferring genetically anomalous embryos, and in declining to assist in such transfers. Principles of reproductive liberty, physician autonomy, and child welfare are invoked in the clinical setting creating challenges in the prioritization and application of these and other principles as clinics work to establish guiding policies". ${ }^{73}$ A case can undoubtedly be made that

65 Asch and Parens, supra note 60.

66 For an account of what would-be parents owe to the children who they seek to create, see (Savulescu 2001). Savulescu argues that "couples (or single reproducers) should select the child, of the possible children they could have, who is expected to have the best life, or at least as good a life as the others, based on the relevant, available information." Savulescu at 415.

67 See (Ethics Committee of the American Society for Reproductive Medicine 2017).

68 Id.

69 I capitalize Deaf where appropriate to signify that the physical state of being deaf is considered to be cultural identity by many members of the Deaf community for whom hearing impairment is not a disability.

70 See (Mundy 2002).

71 See (Karpin 2007).

72 Mundy, supra note 68.

73 ASRM, supra note 67, at 1134. 
having a child who is destined to suffer and die in infancy or as a toddler is a morally suspect choice, though one against which we would not legislate. Similarly, a person with an elevated risk of giving birth to a child with a clubfoot certainly would not be discouraged from experiencing the wonder of procreation using her own gametes. And again, while a moral case might be made about people at risk of passing on Cystic Fibrosis or Huntington's disease or an elevated risk of breast cancer, the law does not countenance denying access to procreation to these people.

In the context of people living with certain kinds of disabilities, the willingness and desire to replicate can be a profound act of self-love and a way to create connection with their child. As one author wrote, "Many parents share a touching faith that having children similar to them will strengthen family and social bonds". ${ }^{74}$ Whether sharing a disability does in fact create closer familial bonds is perhaps a calculation that can only be measured subjectively, but it certainly cannot be anathema across the board and across types of disability.

Women with disabilities may be especially discouraged by parents, friends, healthcare providers and others from having children at all or having children without the use of embryo screening technologies for fear that they will have children like themselves. Only those for whom disability is deeply undesired and thought to be a radical failing would be so bold as to tell a person that she should avoid having a child who is too much like her. By having a child without concern about parenting a child with a disability or with the goal of parenting such a child, people living with disabilities make clear the value that they place on their lives, even when others do not.

\section{Conclusions}

Having a child is often a profoundly selfish act in that it is done to satisfy the needs and desires of people already in existence, not to serve the interests of a person who will come into being. This is an observation of procreative behavior, not a critique of such behavior. While law and policy have long supported this desire for some people, the right to procreate in the first instance and then parent one's children has been hard won for others, and, for still others, it is a right still being pursued. That our right to procreate and parent is recognized by constitutional authority and guiding human rights documents speaks to the importance and centrality of procreation and parenting for many people. Like anyone else, some people living with disabilities want to procreate and law and policy must be shaped so as to support this right. This requires taking steps to ensure that people with disabilities get appropriate education about sex and reproductive health; that healthcare providers and caretakers respect the sexual and procreative desires of competent people with disabilities; and that the state enforce its laws against discrimination and educate employees about the diversity among people with disabilities. Standing alone, none of these shifts will protect all people with disabilities from disparate treatment in the realms of parenting and procreation. Nevertheless, each step toward dismantling the structures that diminish the quality of the lives that disabled people can lead moves us closer to the future that people with disabilities deserve, which includes the right to experience the highs and lows of procreation and parenting and to do so with minimal roadblocks and as much support as can be reasonably mustered on their behalf.

Conflicts of Interest: The author declares no conflict of interest.

\section{References}

Appel, Jacob M. 2010. Sex rights for the disabled? Journal of Medical Ethics 36: 152-54. [CrossRef] [PubMed] Asch, Adrienne, and Erik Parens. 1999. The Disability Rights Critique of Prenatal Testing-Reflections and Recommendations. The Hastings Center Report 29: S1-S22.

Barbanel, Josh. 1988. Return of Children to Deaf Mother Is Ordered. New York Times, April 27.

74 Sanghavi, supra note 13. 
Di Nucci, Ezio. 2011. Sexual rights and disability. Journal of Medical Ethics 37: 158-61. [CrossRef] [PubMed] Engber, Daniel. 2015. The Strange Case of Anne Stubblefield. New York Times Magazine, October 20.

Ethics Committee of the American Society for Reproductive Medicine. 2017. Transferring Embryos with Genetic Anomalies Detected in Preimplantation Testing: An Ethics Committee Opinion. Fertility and Sterility 107: 1130-35.

Ethics Committee of the American Society for Reproductive Medicine. 2016. Provision of fertility services for women at increased risk of complications during fertility treatment of pregnancy: An Ethics Committee opinion. Fertility and Sterility 106: 1319-21.

Euser, Saskia. 2016. The prevalence of child sexual abuse in out-of-home care: Increased risk for children with a mild intellectual disability. Journal of Applied Research in Intellectual Disabilities 29: 83-92. [CrossRef] [PubMed]

Friedman, Carli, and Aleksa L. Owen. 2017. Sexual health in the community: Services for people with intellectual and developmental disabilities. Disability and Health Journal 10: 387-93. [CrossRef] [PubMed]

Johnson, Ida M., and Robert T. Sigler. 2000. Forced sexual intercourse among intimates. Journal of Interpersonal Violence 15: 95-108.

Kaplan, Deborah. 1994. Prenatal Screening and Diagnosis: The Impact on Persons with Disabilities. In Women $\mathcal{E}$ Prenatal Testing. Edited by Karen Rothenberg and Elizabeth Johnson. Columbus: Ohio State University Press, vol. 57, pp. 49-61.

Karpin, Isabel. 2007. Choosing Disability: Preimplantation Genetic Diagnosis and Negative Enhancement. Journal of Law and Medicine 15: 89-103. [PubMed]

Kulick, Don, and Jens Rydström. 2015. Loneliness and Its Opposite: Sex, Disability, and the Ethics of Engagement. Durham: Duke University Press.

Liachowitz, Claire M. 1988. Disability as a Social Construct: Legislative Roots. Philadelphia: University of Pennsylvania Press.

Lombardo, Paul. 2001. Carrie Buck's Pedigree. The Journal of Laboratory and Clinical Medicine 138: $278-80$. [CrossRef] [PubMed]

Lombardo, Paul. 2016. A Century of Eugenics in America: From the Indiana Experiment to the Human Genome Era. Edited by Paul Lombardo. Bloomington: Indiana University Press.

Mundy, Liza. 2002. A World of Their Own. Washington Post, March 31.

Mutcherson, Kimberly M. 2015. Procreative Pluralism. Berkeley Journal of Gender, Law \& Justice 30: 22-75.

National Council on Disabilities. 2012. Report_Rocking the Cradle: Ensuring the Rights of Parents with Disabilities and Their Children; Washington: National Council on Disabilities.

National League for Nursing. 2017. Pregnancy in Women with Disabilities. Available online: http:/ / www.nln.org/professional-development-programs/teaching-resources/ace-d/additional-resources / pregnancy-in-women-with-disabilities (accessed on 20 November 2017).

Reeves, Stefanie. 2013. Protecting the Rights of Parents with Disabilities. Washington: American Psychological Association.

Sanghavi, Darshak M. 2006. Wanting Babies Like Themselves, Some Parents Choose Genetic Defects. New York Times, December 5.

Savulescu, Julian. 2001. Procreative Beneficence: Why We Should Select the Best Children. Bioethics 15: 414-26. [CrossRef]

Smith, S. E. 2014a. Discussing Disabled Sexuality Is a Radical Act. Rewire.Com, October 22.

Smith, S. E. 2014b. The Fight for Reproductive Rights Too Often Excludes Disabled Parents. Rewire.Com, November 7. Solinger, Rickie. 2005. Pregnancy and Power: A Short History of Reproductive Politics in America. New York: NYU Press. Solinger, Rickie. 2013. Reproductive Politics: What Everyone Should Know. Oxford: Oxford University Press.

Southern Poverty Law Center. n.d. Relf v. Weinberger-Sterilization Abuse. Available online: https://www. splcenter.org/seeking-justice/case-docket/relf-v-weinberger (accessed on 20 November 2017).

Spriggs, Merle. 2002. Lesbian Couple Create a Child Who Is Deaf Like Them. Journal of Medical Ethics 28: 283. [CrossRef] [PubMed]

Steinbock, Bonnie. 1994. Reproductive rights and Responsibilities. The Hastings Center Report 24: 15-16. [CrossRef] [PubMed]

Supreme Court of California. 1985. Conservatorship of Valerie N, 707 P.2d 760-793. San Francisco: Supreme Court of California. 
U.S. Department of Health and Human Services. 2017. Preventing Mother-To-Child Transmission of HIV. Available online: https:/ / aidsinfo.nih.gov/understanding-hiv-aids/fact-sheets/20/50/preventing-motherto-child-transmission-of-hiv (accessed on 20 November 2017).

U.S. National Library of Medicine. 2017. What are genome editing and CRISPR-Cas9? Available online: https: / /ghr.nlm.nih.gov/primer/genomicresearch/genomeediting (accessed on 20 November 2017).

Young, Mary Ellen, Margaret A. Nosek, Carol Howland, Gall Chanpong, and Diana H. Rintala. 1997. Prevalence of abuse of women with physical disabilities. Archives of Physical Medicine and Rehabilitation 78: S34-S38. [CrossRef]

(C) 2017 by the author. Licensee MDPI, Basel, Switzerland. This article is an open access article distributed under the terms and conditions of the Creative Commons Attribution (CC BY) license (http://creativecommons.org/licenses/by/4.0/). 